Copyright (C) 2020 University of Bucharest Printed in Romania. All rights reserved

ISSN print: $1224-5984$

ISSN online: $2248-3942$
Rom Biotechnol Lett. 2020; 25(1): 1253-1259

doi: $10.25083 / \mathrm{rbl} / 25.1 / 1253.1259$

Received for publication, September, 12, 2018

Accepted, October, 18, 2018

Original paper

\title{
Vine shoots waste - new resources for bioethanol production
}

\section{LACRIMIOARA SENILA ${ }^{\mathbf{*}}$, EMILIA NEAG ${ }^{\mathbf{1}}$, IULIA TOROK ${ }^{\mathbf{1}}$, OANA CADAR ${ }^{\mathbf{1}}$, ENIKO KOVACS ${ }^{1}$, IOAN TENU ${ }^{2}$, CECILIA ROMAN ${ }^{1}$}

${ }^{1}$ INCDO-INOE 2000, Research Institute for Analytical Instrumentation, 67 Donath Street, 400293, Cluj-Napoca, Romania

${ }^{2}$ University of Agriculture Sciences and Veterinary Medicine, Faculty of Agriculture, Iasi, Romania

\begin{abstract}
The objective of this study was to determine the chemical composition of eight vine shoot waste (VSW) varieties (Sauvignon Blanc, Pinot Noir, Feteasca Regala, Busuioaca de Bohotin, Muscat Ottonel, Cabernet Sauvignon, Feteasca Neagra and Feteasca Alba) regarding cellulose, hemicellulose, lignin, ash, moisture, mineral, protein, elemental analysis for the production of bioethanol. The highest cellulose and hemicellulose content (almost 65\%) suggests that the VSW varieties can be used as raw material for bioethanol production. The most abundant minerals found in the VSW samples were $\mathrm{Sr}, \mathrm{Fe}$ and $\mathrm{Mn}$, which are indicators for vineyard production in Romania. The autohydrolysis fractionation method was applied for the separation of cellulosic and hemicellulosic sugars from the VSW varieties.
\end{abstract}

Keywords Vine shoots, autohydrolysis pretreatment, cellulose, bioethanol.

To cite this article: SENILA L, NEAG E, TOROK I, CADAR O, KOVACS E, TENU I, ROMAN C. Vine shoots waste - new resources for bioethanol production. Rom Biotechnol Lett. 2020; 25(1): 1253-1259. DOI: 10.25083/rbl/25.1/1253.1259

7 *Corresponding author: LACRIMIOARA SENILA, INCDO-INOE 2000, Research Institute for Analytical Instrumentation, 67 Donath Street, 400293, Cluj-Napoca, Romania E-mail: lacri.senila@icia.ro 


\section{Introduction}

Wine growing regions in Romania have an ideal climate for the wine grape. Romania has a vineyard of 217 thousand hectares and produces 6.0 million hl of wine per annum, being ranked $10^{\text {th }}$ in the world and $7^{\text {th }}$ place in Europe (DE SALVO \& al [1]). Currently, there are 1,300 companies in Romania that grow grapes and produce wine, mainly from Vrancea, Bucharest, Prahova, Arad and Iasi. Wine production leads to uncontrolled disposal of large quantities of wastes in the environment. Romania's viticulture is divided into 8 wine regions (Banat, Crisana and Maramures, Dobrogea, Moldova, Muntenia, Oltenia and Transilvania), and 37 production areas (33 red wines, and 67 white wines) (GEANA \& al [2]).

The vine shoot waste (VSW) is the residue resulted after the cutting of vineyard branches, which are usually burned, contributing to global warming by the emission of greenhouse gases (SPIGNO \& al [3]; MANZONE \& al [4]). The use of VSW for biofuel has not yet been studied and there are only few studies about similar biomass in literature data (BURATTI \& al [5]; DÂVILA \& al [6]).

The European Directive 2008/98/EC on waste provides information on waste management, such as: waste type, recycling and recovery process with low impact on the environment.

Currently, the VSW is not valorized, but can be recovered and used for the production of important biofuels, chemicals, and as precursors for food and pharmaceutical industries (DÂVILA \& al [6]; PIZZI \& al [7]). Cellulose, hemicellulose and lignin are the main compounds of VSW. Cellulose can be used for fiber production or it can be converted into bioethanol through the fermentation of glucose. Lignin can be hydrolyzed to polyphenolic compounds which are natural antioxidants and microbial growth inhibitors and hemicellulose can also be converted into bioethanol, or used for the production of important chemicals, such as: succinic acid, itaconic acid, levulinic acid, glucaric acid, aspartic acid, 3-hydroxi-propionic acid, sorbitol, 3-hydroxibutirolactone, xylitol, glycerol, 2,5-furandicarboxylic acid, glutamic acid, furfural etc. (CRABTREE \& al [8]).

In literature different separation methods of important components from woody biomass feedstock are presented, such as steam explosion, ammonia explosion, autohydrolysis, dilute and alkali pretreatment etc., each of them having advantages and disadvantages. Autohydrolysis is an ecological and environmental friendly method because it doesn't involve the use of chemicals; it uses only water for the separation of important components at high temperatures and pressure. Autohydrolysis leads to a liquid fraction, rich in hemicellulose compounds and a solid fraction composed of cellulose and lignin (SANTOS \& al [9]; SPIGNO \& al [3]).

Because the energy derived from fossil fuels is expensive, biomass is an alternative to fossil fuel (LLORENTE \& al [10]; LAZAR \& al [11]). The identification of metals from vineyards depends on the region's wine species cultivated. (GEANA \& al [2]).

The objectives of this study were to:

(a) Compare the chemical composition of eight VSW samples (Sauvignon Blanc, Pinot Noir, Feteasca Regala, Busuioaca de Bohotin, Muscat Ottonel,
Cabernet Sauvignon, Feteasca Neagra and Feteasca Alba) regarding moisture, ash, extractible, cellulose, hemicellulose, lignin, minerals ( Ti, V, Cr, Mn, Fe, Co, $\mathrm{Ni}, \mathrm{Cu}, \mathrm{Zn}, \mathrm{Rb}, \mathrm{Sr}, \mathrm{Cd}, \mathrm{Ba}, \mathrm{Nd}$ and $\mathrm{Pb}$ ), elemental composition $(\mathrm{C}, \mathrm{H}, \mathrm{O}, \mathrm{N}, \mathrm{S})$, in order to evaluate the possibility to obtain bioethanol;

(b) Autohydrolysis of VSW samples in order to separate the cellulose, hemicellulose and lignin from the VSW structures. The chemical composition of solid and liquid fraction was determined and the obtained results were compared.

\section{Materials and Methods}

\section{Chemicals and reagent}

All chemicals used were of analytical reagent grade. Acetic acid, sulphuric acid (98\%), sodium hydroxide, dichloromethane, methanol, ethanol, toluene, acetone, hydrochloric acid, suprapure nitric acid $65 \%$ and hydrogen peroxide 30\% were purchased from Merck (Darmstadt, Germany). Sodium chlorite (80\%) was purchased from Alfa Aesar GmbH \& Co (Karlsruhe, Germany). The derivatization agent $\mathrm{N}$, O-bis (trimethylsilyl) trifluoroacetamide (BSTFA) was purchased from Sigma-Aldrich. All solutions were prepared using ultrapure water $\left(18.2 \mathrm{M} \Omega / \mathrm{cm}, 20^{\circ} \mathrm{C}\right)$ obtained from a Direct-Q3 UV Water Purification System (Millipore, France).

\section{Raw material}

The VSW variety samples (Sauvignon Blanc, Pinot Noir, Feteasca Regala, Busuioaca de Bohotin, Muscat Ottonel, Cabernet Sauvignon, Feteasca Neagra and Feteasca Alba) were procured from the Research Station of the University of Agricultural Sciences "Ion Ionescu de la Brad" from Iași, farm no. 3 "Vasile Adamachi" (Romania). The vine shoots were collected immediately after the pruning operations, oven dried at $60^{\circ} \mathrm{C}$ for $24 \mathrm{~h}$, and then cutter-milled to pass through either a 2 or $0.2 \mathrm{~mm}$ pore size sieve.

\section{Autohydrolysis method on raw material}

Autohydrolysis of wood was carried out in a stainless steel pressure Parr reactor designed for reactions at a maximum pressure of 140 bars, equipped with a Parr 4523 temperature controller (Parr Instruments, Illinois, USA) and $1 \mathrm{~L}$ reaction vessel. Water and VSW samples were mixed in $7 / 1(\mathrm{w} / \mathrm{w})$ liquid to solid ratio and were heated at $150^{\circ} \mathrm{C}$ for 10 minutes residence time and 60 bar pressure. The pretreatment conditions were selected according to our previous work (DAN \& al [12]).

\section{Analysis of the raw material}

The samples moisture was determined by drying in a universal oven (UFE 400, Memmert, Germany) at $105^{\circ} \mathrm{C}$ for 24 hours. The ash content was determined after the incineration of samples at $550^{\circ} \mathrm{C}$ according to ASTM D1102-84 (2007) [13]. The extractible content was determined as residue after the extraction of samples in a SMX Soxhlet extractor (Behr, Dusseldorf, Germany) with ethanol/ toluene $1 / 2(\mathrm{v} / \mathrm{v})$ for 6 hours and dried at $60^{\circ} \mathrm{C}$ for 24 hours.

The cellulose, hemicellulose and lignin content, before and after pretreatment were determined according to TERAMOTO \& al [14]. The cellulose and hemicellulose content was determined as holocellulose content by treating 
biomass with $\mathrm{NaClO}_{2}$ in acetic acid solution (10\%) (repeated for 4 times). The $\alpha$-cellulose content was determined by treating the holocellulose with $17.5 \% \mathrm{NaOH}$ solution. The hemicellulose content was calculated as the difference between the $\alpha$-cellulose and holocellulose content. The lignin content was determined as the insoluble residue in $72 \% \mathrm{H}_{2} \mathrm{SO}_{4}$ at $20^{\circ} \mathrm{C}$ for 4 hours.

\section{Mineral determination}

An amount of $1 \mathrm{~g}$ sample was digested with $5 \mathrm{~mL}$ $\mathrm{HNO}_{3} 65 \%$ and $2 \mathrm{~mL} \mathrm{H} \mathrm{H}_{2} 30 \%$ in closed PTFE vessel using a microwave digestion system (Speedwave MWS-3+, Berghof, Germany) according to the method described by MICLEAN \& al [15]. The digested samples were quantitatively transferred into $20 \mathrm{~mL}$ volumetric flasks and diluted to the mark with ultrapure water. The minor metals content was measured using Elan DRC II ICP-MS (Perkin Elmer, USA), while the major mineral content using ICP-OES Optima 5300D (Perkin Elmer, USA). The calibration standards were prepared from $1000 \mathrm{mg} \mathrm{L}^{-1}$ multi-element standard solutions (Merck, Germany) by appropriate dilutions.

\section{Elemental analysis and protein determination}

The elemental composition was determined by Flash EA 2000 CHNS/O analyzer (Thermo Fisher Scientific, USA) by means of combustion of 2-3 mg sample according to the following standards: ISO 10694:1995 [16], ISO 13878:1998 [17] and ISO 15178:2000 [18]. The protein was calculated using the general factor (6.25).

\section{Analyses for solid and liquid fraction resulted after autohydrolysis}

The solids from autohydrolysis pretreatment were recovered by filtration, washed with water, dried and analyzed for solid yield, cellulose, hemicellulose and lignin content. The solids were analyzed using the same analytical methods as for the raw material. The liquid fraction resulted from autohydrolysis was analyzed for carbohydrates, acetic acid, furfural and 5-HMF content.

The carbohydrates were determined from liquid fraction by using a gas chromatograph 6890N (Agilent Technologies) coupled with a mass spectrometer 5973N MSD (Agilent Technologies) and a capillary column HP-5 MS $(30 \mathrm{~m} \times 0.25 \mathrm{~mm} \times 0.25)$ according to our previous studies (SENILA \& al [19]). The method used was liquid-liquid extraction with dichloromethane: methanol $(2: 1 \mathrm{v} / \mathrm{v})$, oximation and silylation with BSTFA and GC-MS analysis. The furfural and 5-HMF contents were determined by GC-MS after liquid-liquid extraction with dichloromethane according to SENILA \& al [20]).

The concentration of acetic acid was determined by ion chromatography, using a Metrohm 761 Compact IC (Metrohm Ltd., Switzerland) system with suppressed conductivity detection and a Metrosep A Supp 5-100 analytical column. For the IC system, a mixture of $\mathrm{Na}_{2} \mathrm{CO}_{3}$ $\left(0.0027\right.$ mole $\left.\mathrm{L}^{-1}\right)$ and $\mathrm{NaHCO}_{3}\left(0.001\right.$ mole $\left.\mathrm{L}^{-1}\right)$ was employed as eluent, with a flow rate of $1.2 \mathrm{ml} \mathrm{min}^{-1}$.

\section{Statistics}

All determinations were carried out in triplicate and the results were reported as mean value \pm standard deviation (SD).

\section{Results and Discussion}

\section{Chemical characterization of raw materials}

The composition of raw materials used in this study are presented in Table 1.

Table 1. A comparison between the obtained chemical composition of vine shoot residue and those reported in other studies

\begin{tabular}{|c|c|c|c|c|c|c|c|}
\hline Sample & $\begin{array}{c}\text { Moisture (\% } \\
\text { w/w) }\end{array}$ & $\underset{(\% \text { w/w })}{\text { Ash }}$ & $\begin{array}{c}\text { Extractible } \\
(\% \mathrm{w} / \mathrm{w})\end{array}$ & $\underset{(\% \mathrm{w} / \mathrm{w})}{\text { Lignin }}$ & $\begin{array}{l}\text { Cellulose } \\
(\% \mathrm{w} / \mathrm{w})\end{array}$ & $\begin{array}{l}\text { Hemicellulos } \\
\text { e }(\% \mathrm{w} / \mathrm{w})\end{array}$ & Reference \\
\hline $\begin{array}{l}\text { Savignon } \\
\text { Blanc }\end{array}$ & $8.19 \pm 0.01$ & $5.92 \pm 0.02$ & $0.62 \pm 0.03$ & $28.96 \pm 0.30$ & $36.0 \pm 0.23$ & $28.0 \pm 0.16$ & This work \\
\hline Pinot Noir & $8.02 \pm 0.02$ & $5.83 \pm 0.02$ & $1.31 \pm 0.02$ & $28.36 \pm 0.22$ & $40.4 \pm 0.14$ & $20.1 \pm 0.21$ & This work \\
\hline $\begin{array}{c}\text { Feteasca } \\
\text { Regala }\end{array}$ & $8.07 \pm 0.03$ & $6.48 \pm 0.01$ & $1.8 \pm 0.01$ & $32.62 \pm 0.20$ & $35.0 \pm 0.31$ & $23.4 \pm 0.25$ & This work \\
\hline $\begin{array}{c}\text { Busuioaca de } \\
\text { Bohotin }\end{array}$ & $8.20 \pm 0.01$ & $2.69 \pm 0.04$ & $2.3 \pm 0.04$ & $30.36 \pm 0.10$ & $28.8 \pm 0.25$ & $24.5 \pm 0.18$ & This work \\
\hline $\begin{array}{l}\text { Muscat } \\
\text { Ottonel }\end{array}$ & $7.89 \pm 0.02$ & $4.34 \pm 0.06$ & $5.6 \pm 0.03$ & $25.15 \pm 0.40$ & $34.0 \pm 0.29$ & $17.3 \pm 0.11$ & This work \\
\hline $\begin{array}{l}\text { Cabernet } \\
\text { Sauvignon }\end{array}$ & $7.86 \pm 0.01$ & $4.93 \pm 0.01$ & $5.4 \pm 0.02$ & $24.13 \pm 0.21$ & $39.2 \pm 0.19$ & $25.4 \pm 0.20$ & This work \\
\hline $\begin{array}{c}\text { Feteasca } \\
\text { Neagra }\end{array}$ & $7.78 \pm 0.04$ & $6.01 \pm 0.02$ & $5.6 \pm 0.01$ & $26.79 \pm 0.35$ & $29.2 \pm 0.17$ & $23.7 \pm 0.16$ & This work \\
\hline $\begin{array}{l}\text { Feteasca } \\
\text { Alba }\end{array}$ & $8.01 \pm 0.02$ & $5.00 \pm 0.03$ & $6.0 \pm 0.03$ & $25.99 \pm 0.38$ & $29.1 \pm 0.32$ & $26.8 \pm 0.17$ & This work \\
\hline $\begin{array}{l}\text { Cabernet } \\
\text { Sauvignon }\end{array}$ & $59-67$ & 3.0 & 8.5 & 32.5 & 31.4 & 14.8 & $\begin{array}{l}\text { (CORBIN } \\
\& \text { al [21]) }\end{array}$ \\
\hline $\begin{array}{c}\text { Savignon } \\
\text { Blanc }\end{array}$ & $59-67$ & 1.2 & 3.5 & 10.5 & 20.1 & 43.0 & $\begin{array}{l}\text { (CORBIN } \\
\& \text { al [21]) }\end{array}$ \\
\hline $\begin{array}{l}\text { Grape stalks } \\
\text { (Bonarda and } \\
\text { Barbera) }\end{array}$ & 7.09 & 6.11 & 22.61 & 32.35 & 12.19 & 25.7 & $\begin{array}{c}\text { (AMENDO } \\
\text { LA \& al } \\
[22])\end{array}$ \\
\hline Pinot noir & - & 7.66 & - & 32.98 & 37.88 & 14.93 & $\begin{array}{l}\text { (SPIGNO \& } \\
\text { al [3]) }\end{array}$ \\
\hline $\begin{array}{c}\text { Grape stalks } \\
(\text { Vitis vinifera } \mathrm{L} .)\end{array}$ & - & 7.0 & 2.3 & 17.4 & 30.3 & 21.0 & $\begin{array}{c}\text { (PROZIL \& } \\
\text { al [23]) }\end{array}$ \\
\hline
\end{tabular}


All the analyzed VSW samples contain cellulose, hemicellulose and lignin. The cellulose content varied in the following ranges 28.0-40.0\%. All VSW samples contain high lignin (24.1-32.6\%) and cellulose (28.8-40.4\%) content which is in accordance with the literature (CORBIN \& al [21]; AMENDOLA \& al [22]; SPIGNO \& al [3]; PROZIL \& al [23]). The percentages obtained from the analysis of the Cabernet Sauvignon variety were lower compared with the results reported by CORBIN \& al [21] and also in the case of Pinot Noir variety analysis; our results were higher than those reported by SPIGNO \& al [3]. These differences can be attributed to the geographical origin. Essential components of VSW (cellulose and hemicellulose) represented almost
$65 \%$ of the raw material. Other fractions present in the VSW samples, such as ash (2.69-6.48\%) and extractives $(0.62-6.0 \%)$ were determined for a complete characterization of biomass. The major elements such as $\mathrm{Al}, \mathrm{Ca}$, $\mathrm{Fe}, \mathrm{K}, \mathrm{Mg}, \mathrm{Na}, \mathrm{P}, \mathrm{Si}$ and $\mathrm{Ti}$ and minor elements, such as As, Ba, Cd, Co, Cr, Cu, Hg, Mn, Mo, Ni, Pb, Sb, Tl, V and $\mathrm{Zn}$ can form inorganic ash (VARGAS-MORENO \& al [24]). The ash content in the samples was found in the range 2.0-6.0\% and our results are comparable with the results reported by MEDIAVILLA \& al [25]). Generally, the high ash content reduced the heating value of the biomass (VARGAS-MORENO \& al [24]). The elemental analysis of VSW samples were evaluated and presented in Table 2.

Table 2. The elemental compositions and protein content of VSW samples

\begin{tabular}{|c|c|c|c|c|c|c|}
\hline VSW sample & $\mathbf{N}(\boldsymbol{\%})$ & $\mathbf{C}(\boldsymbol{\%})$ & $\mathbf{H}(\boldsymbol{\%})$ & $\mathbf{O}(\boldsymbol{\%})$ & $\mathbf{S}(\boldsymbol{\%})$ & Protein $(\%)$ \\
\hline Savignon Blanc & $1.60 \pm 0.01$ & $43.1 \pm 0.55$ & $6.23 \pm 0.03$ & $45.6 \pm 0.20$ & $<0.01$ & $10.0 \pm 0.04$ \\
\hline Pinot Noir & $0.85 \pm 0.02$ & $43.9 \pm 0.23$ & $5.83 \pm 0.02$ & $46.0 \pm 0.32$ & $<0.01$ & $5.3 \pm 0.03$ \\
\hline $\begin{array}{c}\text { Feteasca } \\
\text { Regala }\end{array}$ & $0.87 \pm 0.05$ & $44.0 \pm 0.30$ & $5.66 \pm 0.01$ & $46.2 \pm 0.21$ & $<0.01$ & $5.5 \pm 0.05$ \\
\hline $\begin{array}{c}\text { Busuioaca de } \\
\text { Bohotin }\end{array}$ & $0.84 \pm 0.03$ & $43.6 \pm 0.67$ & $5.89 \pm 0.06$ & $45.9 \pm 0.09$ & $<0.01$ & $5.2 \pm 0.09$ \\
\hline $\begin{array}{c}\text { Muscat Ottonel } \\
\text { Cabernet } \\
\text { Sauvignon }\end{array}$ & $0.90 \pm 0.05$ & $44.1 \pm 0.32$ & $6.05 \pm 0.09$ & $45.6 \pm 0.16$ & $<0.01$ & $5.6 \pm 0.10$ \\
\hline $\begin{array}{c}\text { Feteasca } \\
\text { Neagra }\end{array}$ & $1.00 \pm 0.02$ & $43.8 \pm 0.33$ & $5.84 \pm 0.06$ & $45.3 \pm 0.31$ & $<0.01$ & $6.6 \pm 0.03$ \\
\hline Feteasca Alba & $1.00 \pm 0.06$ & $44.6 \pm 0.90$ & $6.14 \pm 0.03$ & $45.2 \pm 0.20$ & $<0.01$ & $6.3 \pm 0.05$ \\
\hline
\end{tabular}

The results presented in Table 2 show that all samples have high carbon $(\mathrm{C})$ and oxygen $(\mathrm{O})$ contents, which are in accordance with data reported by EL ACHABY \& al [26] for the elemental analysis of vine shoots from the SupAgro region from Montpellier (France). The elemental analysis showed that carbon varied from $43.1 \%$ in Savignon Blanc to $44.6 \%$ in Feteasca Alba, while hydrogen content ranged from $5.66 \%$ in Feteasca Regala to $6.23 \%$ in Sauvignoin Blanc sample. The VSW is rich in organic carbon, but poor in nitrogen.

All samples contain protein (Sauvignon Blanc has the highest protein content, 10\%). The S content was under the detection limit $(<0.01 \%)$ in all the analyzed samples.

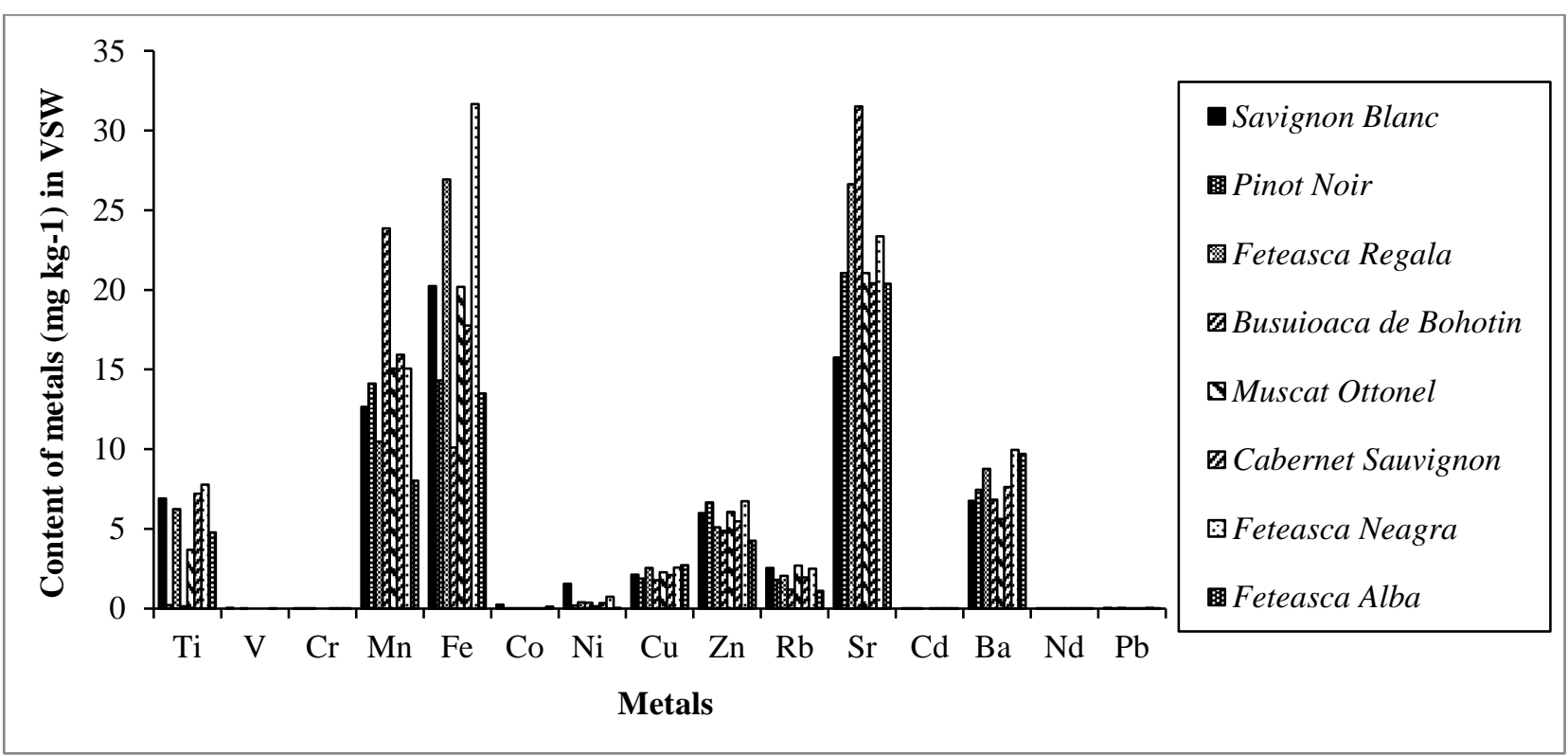

Figure 1. Metal composition in VSW samples 
The presence of inorganic compounds and metals in VSW depend on several factors, such as: grape types, soil characteristics, areas of production and environmental conditions (SIRÉN \& al [27]). The metal content in the analyzed VSW samples varied in the following ranges $\left(\mathrm{mg} \mathrm{kg}^{-1}\right)$ : 15.76-31.51 ( $\left.\mathrm{Sr}\right), 13.5-31.65(\mathrm{Fe}), 8.02-15.95(\mathrm{Mn})$, 5.62-9.95 (Ba), 4.26-6.74 (Zn), 0.15-7.77 (Ti), 1.11-2.69 (Rb), 1.77-2.54 (Cu) (Figure 1). The content of V, Cr, Co, Ni, Cd, $\mathrm{Nd}$ and $\mathrm{Pb}$ was $<1.0 \mathrm{mg} \mathrm{kg}^{-1}$. SPIGNO \& al [3] reported the content of $\mathrm{Cu}, \mathrm{Fe}$ and $\mathrm{Zn}$ from Pinot Noir from Italy to be: $36.2 \mathrm{~g} \mathrm{~kg}^{-1}(\mathrm{Cu}), 49.7 \mathrm{~g} \mathrm{~kg}^{-1}(\mathrm{Fe})$ and $8.7 \mathrm{~g} \mathrm{~kg}^{-1}(\mathrm{Zn})$ which are much higher values compared with our results $\left(0.0018 \mathrm{~g} \mathrm{~kg}^{-1}-\mathrm{Cu}, 0.014 \mathrm{~g} \mathrm{~kg}^{-1}\right.$ for Fe and $0.0066 \mathrm{~g} \mathrm{~kg}^{-1}$ for $\mathrm{Zn}$ ). The most abundant minerals found in the VSW samples were $\mathrm{Sr}, \mathrm{Fe}$ and $\mathrm{Mn}$. The highest $\mathrm{Sr}$ concentration (31.5 mg kg-1) was found in Busuioaca de Bohotin and the highest Fe content $\left(31.65 \mathrm{mg} \mathrm{kg}^{-1}\right.$ ) was found in Feteasca Neagra. According to literature, for Romanian wines, $\mathrm{Mn}$ and $\mathrm{Sr}$ are elements that show the difference between various wine species. Also, $\mathrm{Ba}, \mathrm{Ca}, \mathrm{Mg}$ are metals specific for France and USA regions, $\mathrm{Mn}, \mathrm{P}, \mathrm{Ag}, \mathrm{Ni}$ and $\mathrm{Cr}$ for Hungary and $\mathrm{Rb}, \mathrm{Na}$ and $\mathrm{Fe}$ for Germany (SUHAJ \& al [28]). The results obtained show that $\mathrm{Mn}$ and $\mathrm{Sr}$ were found in high concentration in all the analyzed samples.
The $\mathrm{Cu}$ content is found in low concentration in all the samples $\left(1.88-2.77 \mathrm{mg} \mathrm{kg}^{-1}\right)$ which complies to the maximum allowed $\mathrm{Cu}$ levels (Commission Regulation (EC) No. 1410/2003, 2003): $6 \mathrm{~kg} \mathrm{ha}^{-1}$ year $^{-1}$ and maximum residue limits in vineyard soil $\left(140 \mathrm{mg} \mathrm{kg}^{-1}\right)$, in grapes $\left(30 \mathrm{mg} \mathrm{kg}^{-1}\right)$ and wine $\left(1 \mathrm{mg} \mathrm{L}^{-1}\right)$ (SUN \& al [29]). The concentrations of $\mathrm{Zn}\left(4.26-6.74 \mathrm{mg} \mathrm{kg}^{-1}\right), \mathrm{Cu}\left(1.77-2.54 \mathrm{mg} \mathrm{kg}^{-1}\right)$ and $\mathrm{Pb}$ (0.01-0.04 $\mathrm{mg} \mathrm{kg}^{-1}$ ) found in VSW samples were lower than those reported by VYSTAVAN \& al [30] in leaves (Chardonnay and Muscat samples cultivated in southern Ukraine): average content $28 \mathrm{mg} \mathrm{kg}^{-1}(\mathrm{Zn}), 9.91 \mathrm{mg} \mathrm{kg}^{-1}$ $(\mathrm{Cu})$ and $0.99 \mathrm{mg} \mathrm{kg}^{-1}(\mathrm{~Pb})$.

\section{Autohydrolysis pretreatment}

The VSW samples were subjected to autohydrolysis at $150^{\circ} \mathrm{C}$ for $10 \mathrm{~min}$ and $60 \mathrm{bar}$ pressure. The procedure was based on our previous experience (DAN \& al [12]). The liquid phase and the amount of solid fraction were measured and analyzed. The solid fraction was analyzed for cellulose, hemicellulose and lignin content and the liquid fraction was analyzed for carbohydrates, furfural, 5-HMF content and acetic acid content. Figure 2 shows the data obtained after the analysis of solids resulted from the autohydrolysis pretreatment.

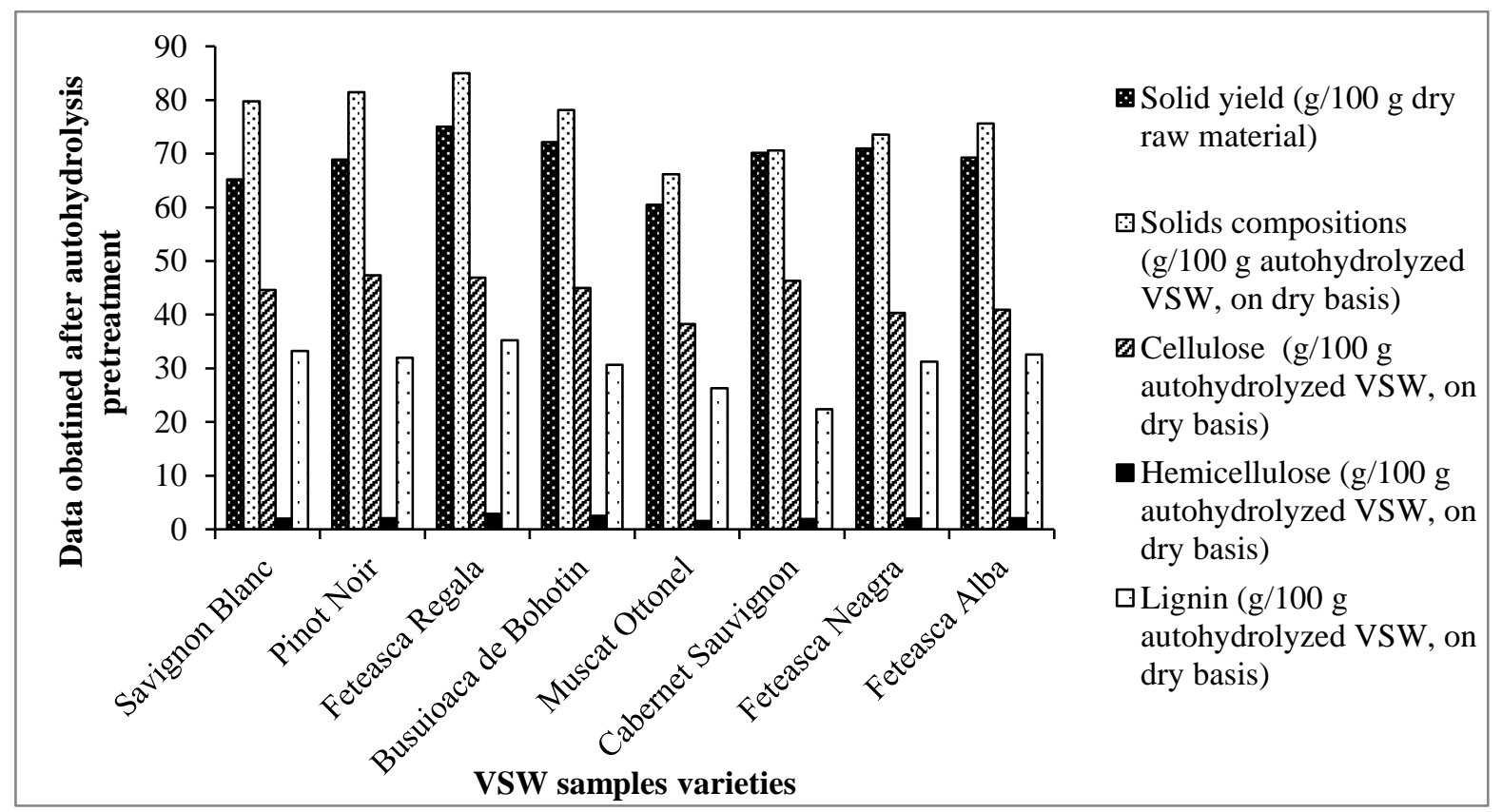

Figure 2. The solid yield and composition of solid fraction of different VSW varieties after autohydrolysis.

The results presented in Figure 2 show that the solid yield of solid recovered after autohydrolysis ranges between 60.5-75.0\%. The highest yield of autohydrolyzed VSW was obtained for the Feteasca Regala variety and the smallest yield was obtained for Muscat Ottonel. In the solid fraction, cellulose ranges between $38.3-47.3 \%$ and lignin ranges between $22.3-35.2 \%$. A very small content of hemicellulose was found in the solid fraction (1.58-2.9\%), which proves that the autohydrolysis method can separate the cellulose in solid fraction and hemicellulose in liquid fraction. The method is based on cellulose and hemicellulose solubility in water at high temperatures and pressure. The composition of the liquid fraction resulted after the autohydrolysis method is shown in Figure 3.

The pentose's (xylose and arabinose) from hemicellulose structure can be degraded into furfural and hexoses (galactose, mannose and glucose) can be degraded into 5-HMF (SENILA \& al [31]). The results presented in 
Figure 3 suggest that the autohydrolysis of VSW varieties separated almost all the hemicellulose fraction in the liquid phase and recovered it as carbohydrates, furfural, 5-HMF and acetic acid. The carbohydrates content from the liquid fraction varied in the following order: Pinot Noir > Feteasca Regala > Feteasca Neagra > Feteasca Alba >
Cabernet Sauvignon > Busuioaca de Bohotin > Muscat Ottonel > Savignon Blanc. Acetic acid was found in all samples, in the range of $0.98-2.29 \%$. The analyzed liquid fraction also contains furfural and 5-HMF, but their content was below $0.1 \%$.

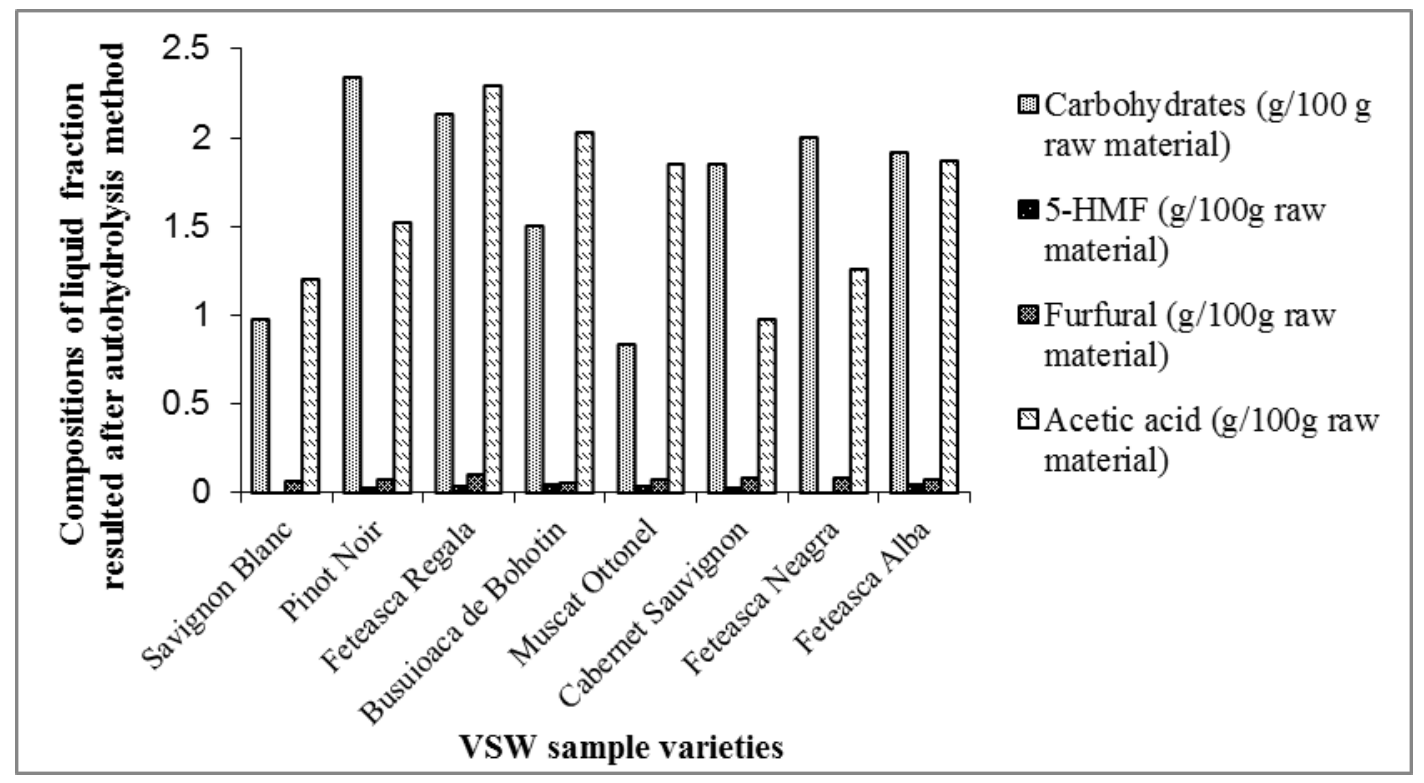

Figure 3. Composition of liquid fraction resulted after autohydrolysis pretreatment.

\section{Conclusion}

A preliminary investigation on the influence of autohydrolysis pretreatment on bioethanol production from VSW was performed. Overall, the results obtained (highest cellulose and hemicellulose content, almost 65\%) in this study suggest the possibility of using VSW as a potential source for bioethanol. Regarding the chemical compositions, there were no major differences observed between the different varieties. $\mathrm{Sr}, \mathrm{Fe}$ and $\mathrm{Mn}$ are the abundant minerals found in all samples which are indicators for vineyard production in Romania.

\section{Acknowledgements}

This work was supported by a grant of the Romanian Ministry of Research and Innovation, CCCDI-UEFISCDI, project number PN-III-P1-1.2-PCCDI-2017 0251/4PCCDI/ 2018 and, within PNCD III and Core Program PN18-28 0201 under the support of ANCS.

\section{References}

1. M. DE SAlVO, D. BEGALli, R. CAPITELlO, G. SIGNORELLO. A spatial micro-econometric approach to estimating climate change impacts on wine firm performance: A case study from Moldavia region, Romania. Agric. Syst., 141: 48-57 (2015).

2. I. GEANA, A. IORDACHE, R. IONETE, A. MARINESCU, A. RANCA, M. CULEA.
Geographical origin identification of Romanian wines by ICP-MS elemental analysis. Food Chem., 138: 1125-1134 (2013).

3. G. SPIGNO, L. MAGGI, D. AMENDOLA, M. DRAGONI, D.M. DE FAVERI. Influence of cultivar on the lignocellulosic fractionation of grape stalks. Ind. Crops Prod., 46: 283-289 (2013).

4. M. MANZONE, E. PARAVIDINO, G. BONIFACINO, P. BALSARI. Biomass availability and quality produced by vineyard management during a period of 15 years. Renew. Energ., 99: 465-471 (2016).

5. C. BURATTI, M. BARBANERA, E. LASCARO. Ethanol production from vineyard pruning residues with steam explosion pretreatment. Environ Prog Sustain Energy, 34: 802-809 (2015).

6. I. DÂVILA, O. GORDOBIL, J. LABIDI, P. GULLÓN. Assessment of suitability of vine shoots for hemicellulosic oligosaccharides production through aqueous processing. Bioresour Technol. 211: 636-644 (2016).

7. A. PIZZI, E.F. PEDRETTI, D. DUCA, G. ROSSINI, C. MENGARELLI, A. ILARI, M. MANCINI. Emissions of heating appliances fuelled with agropellet produced from vine pruning residues and environmental aspects. Renew. Energ., 121: 513-520 (2018).

8. S.P. CRABTREE, R.C. LAWRENCE, M.W. TUCK, D.V. TYERS. Optimize Glycol Production From Biomass. Hydrocarb Process., 85(2): 87-92 (2006).

9. T.M. SANTOS, M.V. ALONSO, M. OLIET, J.C. DOMÍNQUEZ, V. RIGUAL, F. RODRIQUEZ. Effect 
of autohydrolysis on Pinus radiata wood for hemicellulose extraction. Carbohydr. Polym., 194: 285-293 (2018).

10. M.J.F. LLORENTE, J.E.C. GARCÍA. Suitability of thermo-chemical corrections for determining gross calorific value in biomass. Thermochim. Acta, 468: 101-107 (2008).

11. M.D. LAZAR, L. SENILA, M. DAN, M. MIHET. Chapter 10 - Crude bioethanol reforming process: The advantage of a biosource exploitation. Ethanol Science and Engineering, Edit. Elsevier: 257-288 (2019).

12. M. DAN, L. SENILA, M. ROMAN, M. MIHET, M.D. LAZAR. From wood waste to hydrogen - Preparation and catalytic steam reforming of crude bio-ethanol from fir wood. Renew. Energ., 74: 27-36 (2015).

13. ASTM D1102-84 (2007). Standard test method for ash in wood. West Conshohocken, USA: ASTM International; 2007.

14. Y. TERAMOTO, S. LEE, T. ENDO. Pretreatment of woody and herbaceous biomass for enzymatic saccharification using sulphuric acid-free ethanol cooking. Bioresor. Technol., 99: 8856-8863 (2008).

15. M. MICLEAN, O. CADAR, E. LEVEI, L. SENILA, A. OZUNU. Metal contents and potential health risk assessment of crops grown in a former mining district (Romania). J. Environ. Sci. Health., Part B, 0: 1-7 (2018).

16. ISO 10694:1995 - Soil quality - Determination of organic and total carbon after dry combustion (elementary analysis).

17. ISO 13878:1998 - Soil quality - Determination of total nitrogen content by dry combustion (elemental analysis).

18. ISO 15178:2000 - Soil quality - Determination of total sulfur by dry combustion.

19. L. SENILA, A. GOG, M. SENILA, C. ROMAN, L. SILAGHI-DUMITRESCU. Analysis of carbohydrates obtained from wood by gas chromatography-mass spectrometry. Rev. Chim., 62(2): 149-153 (2011).

20. L. SENILA, M. MICLEAN, M. SENILA, M. ROMAN, C. ROMAN. New analysis method of furfural obtained from wood applying an autohydrolysis pretreatment, Rom. Biotechnol. Lett., 1(18): 7947-7955 (2013).

21. K.R. CORBIN, Y.S.Y. HSIEH, N.S. BETTS, C.S. BYRT, M. HENDERSON, J. STORK, S. DEBOLT, G.B. FINCHER, R.A. BURTON. Grape marc as a source of carbohydrates for bioethanol: chemical composition, pre-treatment and saccharification. Bioresor Technol., 193: 76-83 (2015).

22. D. AMENDOLA, D.M. FAVERI, I. EGÜES, L. SERRANO, J. LABIDI, G. SPIGNO. Autohydrolysis and organosolv process for recovery of hemicelluloses, phenolic compounds and lignin from grape stalks. Bioresour Technol., 107: 267-274 (2012).

23. S.O. PROZIL, D.V. EVTUGUIN, L.P.C. LOPES. Chemical composition of grape stalks of Vitis vinifera $L$. from red grape pomace. Ind. Crops Prod., 35: 178-184 (2012).

24. J.M. VARGAS-MORENO, A.J. CALLEJÓN-FERRE, J. PÉREZ-ALONSO, B. VELÁZQUEZ-MARTÍ. A review of the mathematical models for predicting the heating value of biomass materials. Renew. Sust. Energ. Rev., 16: 3065-3083 (2012).

25. I. MEDIAVILLA, M.J. FERNÁNDEZ, L.S. ESTEBAN. Optimization of pelletisation and combustion in a boiler of $17.5 \mathrm{~kW}_{\text {th }}$ for vine shoots and industrial cork residue. Fuel Process. Technol., 90: 621-628 (2009).

26. M. EL ACHABY, N. EL MIRI, H. HANNACHE, S. GMOUH, H. BEN YOUCEF, A. ABOULKAS. Production of cellulose nanocrystals from vine shoots abd their use for the development of nanocomposite materials. I. J. Biol. Macromol., 117: 592-600 (2018).

27. H. SIRÉN, K. SIRÉN, J. SIRÉN. Evaluation of organic and inorganic compounds levels of red wines processed from Pinot noir grapes. Anal. Chem. Res., 3: 26-36 (2015).

28. M. SUHAJ, M. KOREŇOVSKÁ. Application of elemental analysis for identification of wine origin. Acta Aliment., 34(4): 393-401 (2005).

29. X. SUN, T. MA, J. YU, W. HUANG, Y. FANG, J. ZHANG. Investigation of the cooper contents in vineyard soil, grape must and wine and the relationship among them in the Huaizhuo Basin Region, China: A preliminary study. Food Chem., 241: 40-50 (2018).

30. Y. VYSTAVNA, L. RUSHENKO, D. DIADIN, M. KLYMENKO. Trace metals in wine and vineyard environment in southern Ukraine. Food Chem., 146: 339-344 (2014).

31. L. SENILA, M. SENILA, S. COSTIUG, M. MICLEAN, C. VARATICEANU, C. ROMAN. Autohydrolysis of Albies alba wood using adaptive neural fuzzy interference system mathematical modeling. Int. J. Green Energy, 1: 611-624 (2014). 